\title{
Creating a national given-name stock: A CHAPTER FROM THE MODERN-DAY HISTORY OF HUNGARIAN PERSONAL NAMES
}

\author{
TAMÁs FARKaS \\ ELTE Eötvös Loránd University, Budapest, Hungary
}

\begin{abstract}
Proper names often have a symbolic meaning, expressing the taste and values of the community giving and using the names (sacred or profane, national or international, traditional or modern, common or uncommon, etc.). In the age of romanticism, nationalism and revolutions, personal names, as signs of social, cultural or even political renewal, could play a special role, expressing these changes. This paper presents how a set of new, national given names could be created, expanding the traditional given-name stock of ecclesiastic origin ("sacred" in its traditional way) with the new type of national names (a kind of "profane" - or "sacred", but in its "profane" form). The historical and onomastic background, the various sources and methods, and the consequences of these processes are presented in the paper, in the case and example of the Hungarian given-name stock of the 18th-19th centuries, which have much in common with those phenomena of other nations and languages over the last centuries as well.
\end{abstract}

Keywords: national names, language reform, neologism, Hungarian, given names, literary names.

\section{Origins and changes of the Hungarian given-name stock}

The earliest anthroponyms of the Magyars (i.e. Hungarians) known today are from the 9th-10th centuries $\mathrm{AD}$; although a few date from before the Hungarian settlement in the Carpathian Basin (895-900), all of them were recorded afterwards. This name stock bears the characteristics of ancient personal-name systems. Its base layer comprised Hungarian given names of a descriptive nature and motivated by several factors, including the various forms of name magic, according to the beliefs of the people (Slíz 2017a: 100-103). These names were derived from Hungarian common nouns (e.g. male names: Árpád < árpa 'barley' + -d diminutive suffix, Előd 'first-born'; female names: Nyest 'marten', Csala 'cheat'). These were augmented by names loaned from Old Turkic languages and nations, during the Hungarian migration which ended with the conquest of the Carpathian Basin (e.g. male names: Ákos 'white eagle', Ajtony 'gold'; female names: Sarolt 'whiteness, white stoat', Karolt 'blackness, black stoat'). (In detail, see also Hajdú 2003: 347-358, Kálmán 1978: 39-45.)

This name stock was expanded after the settlement and foundation of the Hungarian state and the conversion to Christianity (e.g. Karácsony 'Christmas', from 
a Slavic loanword; Vendég '[settler] of foreign descent', from a Romance loanword; the newer origin of these [male] names is indicated not only by their linguistic origin, but also by the concepts they denote). Secular names borrowed from other languages as anthroponyms also entered the name stock (e.g. male names: Slavic Ladomér, German Ditmar). However, the most drastic change in the name stock was caused by the spread of ecclesiastic names. Following the foundation of the Christian Hungarian Kingdom (1000), the original personal-name stock was slowly but surely overridden by ecclesiastic names. This process spanned several centuries. Ecclesiastic names first appeared among the upper classes; however, they did not become exclusive among secular and ecclesiastic leaders for a long time. The diversity of the names in use could be also illustrated by the names of the Árpád dynasty (1000-1301), the first Hungarian ruling house (Slíz 2000, 2015: 172-174).

However, the former nature of the given-name stock was entirely changed, and the new concept of "sacred" (in its Christian sense) determined its domain. By the 14th-15th centuries there were hardly a handful of given names left from the earlier, non-ecclesiastic (i.e. "profane") stratum. One of the few exceptions is the name Farkas ('wolf'), which is derived from a Hungarian common noun and - probably due to aspects related to name magic - was earlier the most popular secular male given name. However, this name also proved to be suitable in a Christian context, supported by the existence of St. Wolfgang ('wolf'). He may not have had a strong cult in Hungary, but guaranteed a place for the name in the later Christian name stock through his persona and celebration - meanwhile, the original meaning and background of the name could still reinforce later name-giving tendencies (Slíz 2017b: 21-22).

The monopoly of ecclesiastic names (i.e. Christian names of biblical and martyrological origin) made the system of personal name-giving virtually closed and stable. The given-name stock was mostly expanded through the addition of new saints and, in practice, through the formation of Hungarian name variants or diminutive forms of ecclesiastic names (e.g. Petrus 'Peter' > Péter, and Pét, Pete, Petes, Petres etc.; Slíz 2017a: 92-99, Tóth 2016: 252-256). The name of a Hungarian saint was also added to the Christian name stock, i.e. László, of Slavic linguistic origin (< Vladislav), through King Saint Ladislaus of Hungary (ruled in 1077-1095, canonized in 1192; Slíz 2017a: 103-106).

Naturally, in accordance with these changes, the choice and use of given names became considerably less varied. In general, fewer names were employed, while those in use became much more frequent. The name János ('John'), for example, became the most common male given name in Hungary, as its equivalents did in many other European countries. Given names of ecclesiastic origin were semantically opaque elements of Hungarian name use, unmotivated by their meanings, and thus worked simply as referential given names. (For an overview of these questions, see also Hoffmann and Tóth 2015: 153-157, Tóth 2016.)

Protestantism, having done away with the worship of saints, brought some new colours into the fashions of name-giving, but did not intend to upset the framework 
and basic structure of the existing personal name stock. Names were still chosen from the basic layers of ecclesiastic names, even if the concept of their "sacred" character became varied by the denominations. The most relevant difference to note was the potentially different emphasis put on the sources of these names (i.e. biblical names, or the names of saints) as used by members of different denominations. However, these differences in the name-giving of the following centuries are far from exact, varying in time and space, and often not measurable in the proportion of names.

\section{The age of national awakening and anthroponyms}

The demand, opportunity and novel ways for expanding the given-name stock were brought by the late 18th and 19th centuries in the history of Hungarian anthroponymy. (On the topic in general and in its details, see Mikesy 1973, Kálmán 1978: 46 and 49-51, Hajdú 2003: 528-541, Kecskés 2007, Fercsik and Raátz 2009: 12-19; and the following dictionaries and database: Szily 1902-1908. 1: 172 and 2: 499 et passim, Hajdú 1983, Ladó and Bíró 1998, Fercsik and Raátz 2009, Raátz and Sass 2013.)

The age of Enlightenment and classicism was followed by the age of romanticism, as well as the age of national awakening, a period of national cultural, social and political renewal. These were accompanied by an intention to uplift the country and its people both in the material and intellectual sense, an increased interest in the national past, and symbolic nation-building. The agenda of reinforcing and renewing the Hungarian language (especially by coining new Hungarian words) was also a characteristic intention of the time. This was the age of the language reform movement, followed by the socalled Hungarian Reform Era, an era that eventually led to the 1848 revolution and the failed Hungarian War of Independence. It was this context that motivated the renewal and widening of the possibilities of name-giving from a national point of view.

The given-name stock of the period mostly consisted of traditional ecclesiastic names, the form of which had been more or less Magyarized (e.g. Stephanus > István, Andreas > András; Maria > Mária, Catharina > Katalin). The name stock of that time also contained given names newly borrowed from other languages.

The intention and practice of expanding the name stock with Hungarian names to make it more Hungarian was a process that unfolded parallel to the renewal of the Hungarian language and the development of the Hungarian common vocabulary. The reasons behind and goals of both movements were similar in many regards. The first such initiative regarding the personal-name stock can be dated to the last decades of the 18th century, but it only truly unfurled in the 19th century. It should be noted that a few cases of family name changes from names of foreign origin to names of Hungarian origin can also be found in the period. This Magyarization (i.e. Hungari[ani]zation) of surnames, nevertheless, developed more slowly and only became a movement in the middle of and towards the end of the 19th century (Maitz and Farkas 2008, Farkas 2015).

Creating or using new given names (i.e. giving them to newborns) was initially only characteristic of a small segment of society. However, these new given names 
could also have played a model role, demonstrating not only concrete names, but their possible sources, methods of creation, and a more general freedom in namegiving. Influential members of society, works of literature, or even a list of given names published as an appendix of a Latin-Hungarian dictionary could all have played a vital role in the popularization of these new names (cf. e.g. Kálmán 1978: 49). Regional and denominational aspects, on the other hand, were less influential in this process, as it was mainly dominated by sociocultural factors. These factors were the intellectual background of the time, the social groups committed to an ideal of erudition and other bourgeois values, as well as to the idea of a Hungarian nation and culture. (See Hajdú 2003: 537-541, Kecskés 2007: 210-212, cf. also Mikesy 1973.) These changes in the name-giving practices of the given segments of the society can be interpreted also as swapping the old and "sacred" (in its traditional and religious sense) for the new and that kind of "profane", but also as changing for a new kind of "sacred" of the era, i.e. the 'national' content. This process, however, did not necessarily mean a break with religious values (several of its leading figures also were clerics), but it was a sign of the new ideology gaining dominance in this symbolic field as well.

The new elements of the Hungarian name stock also appeared in the given-name stock of ethnic groups or nations living in Hungary soon. Similar processes in their respective national given-name stocks also came to light. Naturally, processes like those presented here, connected to similar historical, social, cultural and (linguistic) ideologies, ran their course in the name stock of many other countries and peoples.

The history of the given-name stock and name-giving tendencies in Estonia, for example, offers interesting similarities and differences. (The Hungarian language reform might well have served as a model for the Estonian efforts as well. Otherwise, both languages belong to the Finno-Ugric language family, but the history of the two nations are quite different.) The trend of giving "national names" occurred in Estonia about a century later than in Hungary, due to historical, social and cultural factors, while their influence was less lasting. However, the background and the working mechanisms of the phenomenon itself show many similarities with those in Hungary, and also the types and sources of these new given names. (See Hussar 2007 or for a comparative approach involving more factors, Hussar and Rüütmaa 2017.) The study of these questions, then, is also a fruitful field of further research with a wider scope of potential lessons to learn.

\section{The creation of a national given-name stock}

The expansion of the existing given-name stock in the late 18th and 19th centuries was influenced by a variety of sources and typical procedures, most typically by (i) the renewal of old given names, (ii) the formation of new names, (iii) equivalents of foreign given names, (iv) the creation of female counterparts for existing male names. 


\section{The renewal of old given names}

Personal names borne by figures from the pre-Christian period of Hungarian history or the early centuries of the Hungarian Kingdom were taken from medieval sources. A number of names were associated with great personages (chieftains, kings, heroes etc.), while others could be more or less simply be regarded as names based in the national past. Names of historic and legendary characters were used as well.

Medieval sources were or became known in the period, such as the Gesta Hungarorum (written at the beginning of the 13th century, containing an imagined account of the settlement of the Magyars in the Carpathian Basin), which included several fictitious events and characters, but its historical credibility was not questioned at the time (Anonymus 1772). Several Old Hungarian given names were propagated by the name list added as an appendix by Péter Bod to the 1767 edition of the LatinHungarian Dictionary (Dictionarium Latino-Hungaricum, 1708) of Ferenc Pápai Páriz (see Fekete 1991). The revival of names from historical sources (those from the Gesta Hungarorum among them) was often aided by works of historical fiction written in the period, as these mediated and popularized them among the contemporary audience.

The potential pool of names was outlined by the contemporary knowledge or, even more, by the romantic perception of the national past. Thus, this pool of names also included the history of Attila the Hun and his people, considered predecessors of the Magyars at the time. Therefore, such names as Attila Etele or Aladár and Csaba (the sons of Attila in medieval fictional tradition) were introduced into the given-name stock as well. The list of revived old names was later lengthened with names such as Zalán, which, according to the fictitious events in the Gesta Hungarorum, was the name of the leader of a faction hostile towards the conquering Magyar tribes. Regardless of their particular contexts these names have remained elements of the given-name stock and many of them are also popular today.

Some of the renewed names are transparent and of Hungarian linguistic origin, i.e. come (or at least seemingly come) from common nouns (e.g. male names: Bors 'pepper'; female names: Ajándék 'present'). Others are non-transparent and of foreign origin (e.g. Old Turkic male names: Tas and Zoltán from early Hungarian history; German male name Aladár and female name Ildikó from the Hun story; Slavic male name Tihamér from early sources, etc.). The origin of some of the names is unknown (e.g. Béla, the name of four kings of the Árpád dynasty, which may be derived from the Hungarian common noun bél 'inner part', an Old Turkic word for dignitary, or from the Bible). Alongside them, old Hungarian variants of ecclesiastic given names (e.g. Endre and Andor, historical versions of András < Andreas 'Andrew') can also be found.

From the perspective of historical onomastics, it should be noted that names from historical sources were revived according to how they were read at the time (Fercsik and Raátz 2009: 18). As a result, the phonetic form of several names changed - compared to their probable past pronunciation. Thus, for example, the male name of Old Turkic origin Zoltán ('a kind of dignity', a word also related to the word sultan) 
entered use through spelling pronunciation with a $z$-, instead of the original s-. A similar phenomenon occurred in the case of Géza, in addition to which variants aimed to approximate the original form more exactly (Décse, Gejza, Gyécsa etc.) were also created later.

The national character of these names is not derived from their Hungarian linguistic origins (indeed several cannot be traced to Hungarian), but rather from their connection to the early centuries of Hungarian history and also from their not being characteristically foreign (i.e. they do not belong to the name stock of an easily recognisable and well-known foreign language). Moreover, names of Old Turkic origin, as they were borrowed before the settlement of the Carpathian Basin, were listed as elements of the national name stock; this tendency could have been underpinned by their phonetic similarity to Hungarian and at the time supposed kinship between the Hungarians and Turkic peoples.

\section{The formation of new names}

Intellectuals, especially the writers and poets of the period, made a substantial number of additions to the Hungarian given-name stock (Kovalovszky 1934: 50-62 passim, Slíz 2016: 249-251). A list of important figures in Hungarian literary history who created names: András Dugonics, the writer of the first original Hungarian novel, Etelka (1788); Mihály Vörösmarty, the poet who created the national epic, The Flight of Zalán (1825); János Arany, a leading figure of national lyrical and epic poetry (1817-1882); Mór Jókai, the most celebrated novelist of the second half of the 19th century (1825-1904); etc. Many of the names created were showcased in epic works of a historical nature, which proved extremely popular in the period. These new names were mostly used alongside names taken from historical sources (or even other literary works). Thus, a significant number of these names were introduced as the designations of fictitious figures, and name givers would take them from literary sources to give them to their newborn children.

These new names were coined following different patterns. Some were created from Hungarian common nouns using the different ways of creating neologisms (e.g. female names Imola < imola 'centaurea [genus of plants], the name of several flowers'; Tünde < tündér 'fairy'; Gyöngyvér < Gyöngy 'pearl' and testvér 'sibling'). Other names were created based on or by using the elements or models of existing Hungarian or foreign names (e.g. female names Tímea < Greek Euthümia; Jolán < Jólánka < old Hungarian Jóleány < jó + leány 'good maiden', cf. also Greek Jolanta 'Yolanda', cf. Slíz 2017c: 147-152; etc.).

The border between the creation of new names and the revival of old names was far from clear. Furthermore, both methods can largely be traced to the work of poets and writers, thus strengthening the literary influence on the Hungarian name stock, which has had an effect lasting to the present day. 


\section{Hungarian equivalents of foreign given names}

The practice of creating or determining a suitable Hungarian equivalent of foreign given names also existed (see e.g. Ladó 1980: 1153-1154). The intention of this practice was partly to expand the Hungarian name stock, partly to replace foreign names with Hungarian ones.

A method used often was to simply translate names that had easily identifiable meanings (e.g. male names: Konstantin > Szilárd 'solid, firm', Viktor > Gyöző 'victor'; female names: Viola > Ibolya 'violet'; Auróra $>$ Hajnalka 'dawn $+-k a$ diminutive suffix', Angelika > Angyalka 'Angel + -ka diminutive suffix'). In some cases, this method coincided with the practice of reviving old Hungarian names (e.g. male names: Félix $\sim$ Bódog or Boldog 'happy'; female names: Flóra Virág 'flower'). Sometimes attempts were made to Magyarize foreign names only partially, considering nothing but their form, especially in the case of male names (e.g. Rudolf > Rezsö, Ernest > Ernö, Ireneusz > Jernö; following the phonetic example of the medieval Hungarian name form Dezsö 'Desiderius'). In the majority of cases both the foreign given names and their new Hungarian equivalents have remained elements of the Hungarian name stock.

It is worth mentioning in connection with this topic that, in some cases, foreign names were correlated with new or renewed Hungarian ones only based on superficial formal similarity and convention (e.g. Latin Julius etc. Old Turkic/Hungarian Gyula, French Charlotte Old Turkic Sarolt). Some of these equivalencies were subject to fluctuation (Szily 1902-1908. 1: 172). For example, the Hungarian substitute of Eugen (< Eugenius 'Eugene', of Greek origin) could have been Jenö or Ödön. While that was forgotten in time, from a historical perspective the linguistic descendant of Eugen in Hungarian is Ödön, which eventually became the equivalent of Edmund. Meanwhile, Jenö, a name of completely different descent and meaning (the Old Turkic name of one of the Hungarian tribes), became the Hungarian equivalent of Eugen. (A literary imprint of this fluctuation can be found in one of Mór Jókai's classics, which is compulsory reading material for students to this day. In detail, see Farkas 2009: 27-32.)

The above-mentioned correspondences also meant that these arbitrary equivalencies were used in the practice of translating the names of foreign figures (or literary characters), a common procedure in the period (e.g. Jules Verne > Verne Gyula, Yevgeniy Onegin $>$ Anyegin Jenö etc.). However, the "translation" of foreign given names, commonly used in Hungarian in the 19th century, ceased in the 20th century, and only remained in a few rare cases (e.g. now: Jules Verne is Jules Verne, but Prinz Eugen von Savoyen still remains in its - otherwise posthumously - Magyarized form: Savoyai Jenő herceg).

\section{The creation of female counterparts for existing male names}

The smaller pool of traditional female given names, as well as their more foreign general character made it necessary to dedicate special care and attention to this question. Male-female name pairs were originally - due to linguistic characteristics non-existent in the Hungarian language. However, the European name stock provided 
such examples and thus ideas for the creation of female counterparts for existing male given names. Their creation was often also motivated by the intention to replace female names of foreign origin with Hungarian equivalents.

The female equivalents of male names were created using diminutive suffixes or diminutive forms previously used as male names were used as female names (cf. e.g. Horváth 1913). Only few of these remain in use today, and most of them are rare (e.g. János 'John' + -ka suffix > Janka 'Joan'; József 'Joseph' + - a suffix > Józsa 'Josephine'; György 'George' + -i suffix > Györgyi 'Georgina'). Similar names were also formed from new, national male given names (e.g. Jenő 'Eugene' + -ke diminutive suffix > Jenöke 'Eugenia', Szilárd 'Constantine' + -ka diminutive suffix > Szilárdka 'Constance').

New, quasi "female-name" suffixes were also adapted as typical name endings from foreign female names (cf. Mikesy 1973: 230, 231, 235). They were generally used for the suffixation of new national male names, thus coining new female names (e.g. Zoltán +-a > Zoltána; Árpád + -ia or -ina > Árpádia and Árpádina; Andor + -in or -ina > Andorin and Andorina). However, these names never became common or long-lasting elements of the female name stock.

\section{Methods for the creation of names}

The creation of names for each gender was also influenced by a number of external factors. Male names were easy to find and thus revive from historical sources. Female names were rarer in these sources; therefore, the creation of names became a more influential method in their case.

The procedures discussed above could also play together in the creation of new names. See, for example, the case of Etelka, a female given name in the novel with the same title, the first original Hungarian novel, written in 1788 by András Dugonics and set in an imaginary ancient Hungarian historical period. The name was coined as a female name from the revived male name Etele 'Attila' (a name variant for the name of Attila the Hun) + -ka diminutive suffix, but might have also followed the model of Adel and Adelka. The root of the name is thus of historical origin, from which a female pair was created through literary name-giving, later entered common use, and is an active element of the name stock to the present day. To offer another example: the name Nandor could be considered the equivalent or a diminutive form of German Ferdinand. However, the name also coincided with an old Hungarian word (an ethnonym, nándor 'Bulgarian'), which was no longer in common use, but was still known as an element of a symbolic location (Nándorfehérvár 'Belgrade', the site of a victory against the invading Ottoman Empire). The name was also similar to the common onym Sándor 'Alexander'. Its female counterpart was created later, but quite unsuccessfully: Nándorka (Mikesy 1973: 239).

The methods for the creation of a new, national name stock were those listed above, which often worked to strengthen each other. Different methods of name creation were sporadic at best. The use of the name Petöf as a given name, from the surname of the poet and revolutionary Sándor Petöfi, is an example in this respect (Mikesy 1992: 13-14). While other examples can be listed from the period (e.g. Garibaldi, from 
the surname of the Italian general Giuseppe Garibaldi), name creation of this type was never truly common in Hungarian name-giving.

\section{The afterlife of the national name stock}

Similar to the new words of the language reform movement in Hungary, many names or name types were unsuccessful in the creation or propagation of the national name stock. Some of the new names proved to be ephemeral. Others, however, have become popular and feature heavily even in the contemporary given-name stock.

For example, from this category in Hungary one could find last year (in 2016) 5 male names (Zoltán - 5th, Attila - 9th, Zsolt - 12th, Csaba - 15th, Gyula - 20th) and a female name (Ildikó - 13th) from the top 20 male and female names of the whole population; and 4 male names (Levente - 3rd, Zalán - 11th, Botond - 16th, Zsombor 19th) and 3 female names (Boglárka - 8th, Lilla - 17th, Réka - 20th) of the top 20 baby names (Lakossági számadatok 2017).

The new names gradually earned a place among the extant traditions of name giving and name use: much later, name days and, for the sake of Catholic name givers, patron saints were assigned to them, and so on.

These procedures and ways of expanding the given-name stock - among others - still exist (cf. Raátz 2002, 2003 and 2008, Fercsik and Raátz 2009: 15-19), contributing to the enrichment of the relatively closed and - from the 20th century - also officially regulated possibilities of Hungarian name-giving even nowadays.

\section{References}

Anonymus. 1772. Anonymi Belae regis notarii Historia Hungarica de septem primis ducibus Hungariae. Cassovia: Collegii Academici Societatis Jesu.

Farkas, T. 2009. A tulajdonnevek fordításának alapkérdéseiről. Diadal vagy Viktória, Eugén vagy Jenó? Fordítástudomány 11 (2): 22-35.

Farkas, T. 2015. Changing Names as Abolishing the Difference: Personal Names as Ethnic Symbols, Characteristics of Surname Changes and the Magyarization of Surnames in Hungary. Létünk 45 (3): 27-39.

Fekete, A. 1991. Keresztneveink nyomában. Budapest: Magyar Nyelvtudományi Társaság.

Fercsik, E. and J. Raátz. 2009. Keresztnevek enciklopédiája. A leggyakoribb női és férfinevek. Budapest: Tinta Könyvkiadó.

Hajdú, M. 1983. Magyar-angol, angol-magyar keresztnévszótár. Hungarian-English, EnglishHungarian Dictionary of Christian Names. Budapest: ELTE.

Hajdú, M. 2003. Általános és magyar névtan. Budapest: Osiris Kiadó.

Hoffmann, I. and V. Tóth. 2015. Viewpoint on the Cognitive-Pragmatic Description of Personal Names. Word 61 (2): 141-164.

Horváth, E. 1913. Ferike, Lipótka és társaik. Magyar Nyelvőr 42 (6): 277-278.

Hussar, A. 2007. New Estonian Names a Hundred Years Ago. In Proceedings of the 21st International Congress of Onomastic Sciences. Uppsala 19-24 August 2002: Vol.2, E. Brylla and M. Wahlberg (eds.), 143-150. Uppsala: Institutet för språk och folkminnen.

Hussar, A. and T. Rüütmaa. 2017. Original Given Names in Estonian and Hungarian. Paper presented at the 26th International Congress of Onomastic Sciences, Debrecen. 
Kálmán, B. 1978. The World of Names. A Study in Hungarian Onomatology. Budapest: Akadémiai Kiadó.

Kecskés, J. 2007. „Nemzeti nevek” és a nemzeti öntudatra ébredés nevei. In Nyelvi identitás és a nyelv dimenziói, I. Hoffmann and D. Juhász (eds.), 209-216. Debrecen and Budapest: Nemzetközi Magyarságtudományi Társaság.

Kovalovszky, M. 1934. Az irodalmi névadás. Budapest: Magyar Nyelvtudományi Társaság.

Ladó,J. 1980. Keresztnevek lefordítása. In Nyelvmüvelő kézikönyv I., L. Grétsy and M. Kovalovszky (eds.), 1152-1155. Budapest: Akadémiai Kiadó.

Ladó, J. and Á. Bíró. 1998. Magyar utónévkönyv. Budapest: Vince Kiadó.

Lakossági számadatok 2017. = Utónév statisztika; Utónév statisztika az elözö évben születettek körében. http://www.nyilvantarto.hu/hu/statisztikak (accessed in October 2017).

Maitz, P. and T. Farkas. 2008. Der Familienname als Nationalsymbol. Über den Untergang deutscher Familiennamen im Ungarn des 19. Jahrhunderts. Zeitschrift für germanistische Linguistik 36 (2): 163-196.

Mikesy, S. 1973. Ismeretlen keresztnevek. Magyar Nyelvőr 97 (2): 229-241.

Mikesy, S. 1992. Ismeretlen keresztnevek II. Névtani Értesítő 14: 11-15.

Raátz, J. 2002. Női neveink az Új magyar utónévkönyvben. In Köszöntő kötet B. Gergely Piroska tiszteletére, E. Gréczi-Zsoldos and M. Kovács (eds.), 151-154. Miskolc: Miskolci Egyetem Magyar Nyelvtudományi Tanszéke.

Raátz, J. 2003. Acél vagy Zserald? Az újonnan anyakönyvezhető férfineveinkről. Névtani Értesitő 25: $181-185$.

Raátz, J. 2008. Trends in the Choice of First Names in Hungary since the Second Half of the 20th Century. In Proceedings of the 22nd International Congress of Onomastic Sciences, vol. 2, M. G. Arcamone, D. de Camilli and B. Porcelli (eds.), 195-207. Pisa: Edizioni Ets.

Raátz, J. and B. Sass. 2013. Utónévkereső. http://corpus.nytud.hu/utonevportal (accessed in October 2017).

Slíz, M. 2000. Az Árpád-ház névadása Géza fejedelemtől III. Andrásig. Budapest: ELTE.

Slíz, M. 2015. Byzantine Influence on the Name-giving Practises of the Hungarian Árpád Dynasty. In Byzance et l'Occident II.: Tradition, transmission, traduction, E. Egedi-Kovács (ed.), 171-180. Budapest: ELTE Eötvös József Collegium.

Slíz, M. 2016. Personal Names Originating from Literature or Motion Picture in the Hungarian Name Stock: A Historical Survey. In 'Names and Their Environment'. Proceedings of the 25th International Congress of Onomastic Sciences, Glasgow, 25-29 August 2014, C. Hough and D. Izdebska (eds.), 247-254. Glasgow: University of Glasgow. http://www.icos2014.com/ wp-content/uploads/icos2014_v3_247.pdf (accessed in October 2017).

Slíz, M. 2017a. Personal Names in Medieval Hungary. Hamburg: Baar-Verlag.

Slíz, M. 2017b. Személynévtörténeti vizsgálatok a középkori Magyarországról. Budapest: Magyar Nyelvtudományi Társaság.

Slíz, M. 2017c. Jolánta, un prénom d'origine française dans le Hongrie médiévale. In "M'en anei en Ongria". Relations franco-hongroises au Moyen Âge II., A. Györkös and A. Kiss (eds.), 143156. Debrecen: MTA-DE Lendület Kutatócsoport.

Szily, K. 1902-1908. A magyar nyelvujitás szótára. A kedveltebb képzőkés képzésmódok jegyzékével: Vol.1-2. Budapest: Hornyánszky Viktor.

Tóth, V. 2016. Személynévadás és személynévhasználat az ómagyar korban. Debrecen: Debreceni Egyetemi Kiadó. 